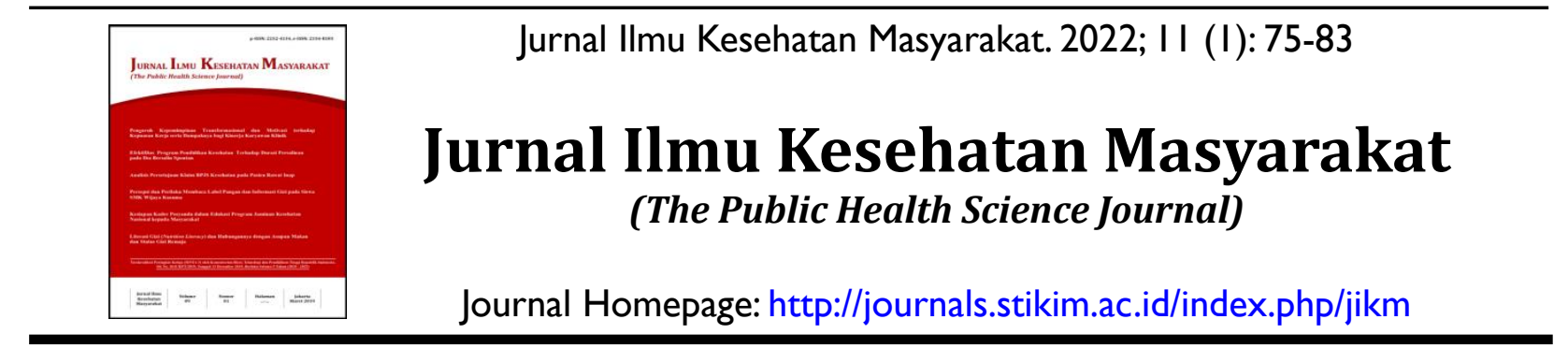

\title{
Faktor-faktor yang Berhubungan dengan Kadar HbA1c Anggota Klub Prolanis Diabetes Mellitus Tipe 2
}

\author{
Azrimaidaliza ${ }^{1}$, Annisa², Rauza Sukma Rita ${ }^{3}$ \\ 1,2 Fakultas Kesehatan Masyarakat, Universitas Andalas, Padang \\ ${ }^{3}$ Fakultas Kedokteran, Universitas Andalas, Padang
}

\begin{abstract}
Abstrak
Penyakit Diabetes Mellitus (DM) merupakan salah satu penyakit yang dapat menyebabkan kematian. Hasil riset kesehatan menunjukkan adanya peningkatan kejadian DM terutama tipe 2 di Indonesia. Penelitian ini bertujuan untuk mengetahui faktor yang paling berhubungan dengan kadar HbAlc anggota klub prolanis Diabetes Melitus tipe 2. Penelitian ini menggunakan desain studi cross sectional. Populasi penelitian adalah seluruh anggota Klub Prolanis Diabetes Mellitus tipe 2 di Puskesmas Lubuk Buaya dan Puskesmas Ambacang, Kota Padang berjumlah 92 orang. Sampel penelitian adalah anggota Klub Prolanis Diabetes Melitus tipe 2 di Puskesmas Lubuk Buaya dan Puskesmas Ambacang berjumlah 83 orang yang diambil secara simple random sampling. Kuesioner terstruktur dipergunakan dalam menggali informasi tentang asupan makanan, aktifitas fisik dan karakteristik sampel penelitian. Analisis data menggunakan uji chi-square, T-independent dan regresi linier ganda dengan Program SPSS. Hasil penelitian menunjukkan bahwa asupan energi $(P v=0,021)$, serat $(\mathrm{Pv}=0,005)$ dan aktifitas fisik ( $\mathrm{Pv}=0,00 \mathrm{I})$ berhubungan secara bermakna dengan peningkatan kadar $\mathrm{HbAIC}$ anggota Klub Prolanis Diabetes Melitus tipe 2. Aktifitas fisik merupakan faktor yang paling berhubungan dengan peningkatan kadar HbAlc anggota Klub Prolanis Diabetes Melitus tipe 2 ( $P v=0,001 ; \beta=-0,425)$. Perlunya kombinasi antara pengaturan makanan yang seimbang dan aktifitas fisik yang teratur dalam menjaga kadar HbAlc sehingga anggota klub memiliki status kesehatan yang terkontrol.
\end{abstract}

Kata Kunci: Aktifitas fisik, asupan makanan, diabetes mellitus, HbAlc, klub prolanis.

\begin{abstract}
Diabetes Mellitus (DM) is a disease that can cause death. The results of health research show an increase in the incidence of DM, especially type 2 in Indonesia. This study aims to find out the factors most related to HbA Ic levels of type 2 Diabetes Mellitus among Prolanis club members. The study used cross-sectional study design. Population was all member of type 2 diabetes mellitus Prolanis Club in the Lubuk Buaya and Ambacang Health Centre, Padang city, totally was 92 members. Sample was member of type 2 diabetes mellitus Prolanis Club in the Lubuk Buaya and Ambacang Health Centre, about 83 members which was taken by simple random sampling. The structured questionnaire was used in collecting information about food intake, physical activity and characteristics of the study sample. Data were analyzed using chi-square, t-test independent and multiple linear regression with the SPSS Program. The results of this study show that energy intake $(P v=0,021)$, fiber intake $(P v=0,005)$ and physical activity $(P v=0,00 I)$ are significantly related to $\mathrm{HbA} I \mathrm{C}$ levels of Type 2 Diabetes Mellitus Prolanis Club members. However, physical activity is the dominant factor which related with $\mathrm{HbAl}$ c level Prolanis Club member of type 2 Diabetes Mellitus $(P v=0,00 \mathrm{I} ; \beta=-0,425)$. The combination of a balanced diet and regular physical activity are needed in maintaining HbA /c levels so that club members of Diabetes Mellitus sufferers have controlled health status.
\end{abstract}

Keywords: Physical activity, food intake, diabetes mellitus, $\mathrm{HbA} / \mathrm{c}$, prolanis club.

Korespondensi*: Azrimaidaliza, Fakultas Kesehatan Masyarakat, Universitas Andalas, Jl. Perintis Kemerdekaan No.94 Padang, E-mail: azrimaidaliza@ph.unand.ac.id, No.Telp: +628/363578067 


\section{Pendahuluan}

Penyakit Diabetes Melitus (DM) terutama tipe 2 merupakan salah satu penyakit degeneratif yang meningkat prevalensinya di negara berkembang termasuk Indonesia. Berdasarkan data World Health Organization (WHO) diperoleh informasi penyakit Diabetes Melitus merupakan salah satu penyakit penyebab kematian utama di dunia dengan jumlah kematian sebesar 1,6 juta jiwa. ${ }^{1}$ Penyakit ini juga diasosiasikan dengan berbagai komplikasi termasuk gagal ginjal, kebutaan, peningkatan infeksi, penyakit jantung koroner dan stroke. ${ }^{2}$

Menurut data International Diabetes Federation (IDF), Indonesia merupakan negara ke-7 dengan kasus DM terbanyak di dunia yaitu sebanyak 10 juta jiwa dan diperkirakan meningkat menjadi menjadi 16,2 juta jiwa pada tahun 2040. Peningkatan terutama terjadi pada penderita DM tipe 2 dari $90-95 \%{ }^{3}$ Hasil Riset Kesehatan Dasar (Riskesdas) diketahui adanya peningkatan prevalensi DM pada tahun 2018 dibandingkan tahun 2013 dari 1,1\% meningkat menjadi 2,1\%. ${ }^{4,5}$ Kemudian prevalensi DM yang terdiagnosis dokter di Provinsi Sumatera Barat mencapai $1,3 \%$ dan $1,4 \%$ di Kota Padang. ${ }^{5}$

Salah satu metode yang dapat digunakan dalam menegakkan diagnosis DM tipe 2 adalah melalui penentuan kadar $\mathrm{HbAlc}$ (hemoglobin terglikosilasi). WHO tahun 2011 menyatakan kadar HbAlc sebagai standar pelayanan dalam pemeriksaan dan monitoring diabetes khususnya DM tipe $2{ }^{6}$ Metode ini dapat menilai kegagalan produksi insulin, resistensi insulin, atau berkurangnya sensitivitas insulin pada negara berpendapatan rendah dan sedang. Peningkatan kadar HbA1c diidentifikasi secara signifikan sebagai faktor risiko penyakit kardiovaskuler dan stroke pada penderita DM. ${ }^{7}$ Faktor-faktor yang dapat mempengaruhi kadar HbAlc adalah perubahan pola makan yang cenderung tidak sehat dan tidak seimbang seperti rendah asupan serat dan tinggi asupan lemak. ${ }^{8}$ Genetik atau adanya keluarga yang memiliki riwayat menderita DM juga salah satu faktor yang mempengaruhi peningkatan kadar HbA1c. Salah satu orang tua menderita DM maka anak berisiko menderita DM sebesar 15\% dan apabila kedua orang tua memiliki DM maka anak berisiko menderita DM sebesar 75\%. ${ }^{9}$ Penelitian terdahulu menunjukkan hasil yang tidak konsisten mengenai faktor-faktor yang berhubungan dengan kadar HbAlc. Untuk itu, perlu penelusuran lebih mendalam mengenai faktor makanan terutama makanan tertentu dan faktor non makanan dalam mengontrol kadar $\mathrm{HbAlc}$ terutama pada penderita DM tipe 2 yang mengikuti kegiatan Program Pengelolaan Penyakit Kronis (Prolanis) di Puskesmas.

Prolanis merupakan salah satu program promotif dan preventif di Puskesmas untuk pengelolaan dan penatalaksanaan kesehatan yang baik, sehingga diharapkan akan menghasilkan kualitas hidup yang optimal walaupun menderita penyakit kronis seperti DM. ${ }^{10}$ Program ini sudah terlaksana sekitar dua tahun di seluruh Puskesmas di Kota Padang. Dari beberapa Klub Prolanis, pelaksanaan kegiatan Prolanis yang cukup baik adalah di Puskesmas Lubuk Buaya dan Puskesmas Ambacang. Hal ini terlihat dari kegiatan senam dan pengukuran kadar gula darah puasa yang rutin dilakukan dua kali dalam satu minggu. Sedangkan kegiatan pengukuran kadar HbA1c dilakukan sekali dalam 3-6 bulan. Menurut survei awal yang dilakukan, diperoleh informasi bahwa terdapat sebanyak 92 orang anggota Klub Prolanis dengan kadar HbA1c yang bervariasi antara $<6,5 \%$ dan $>6,5 \%$. Berdasarkan hal tersebut, tujuan penelitian adalah untuk mengetahui faktor yang paling berhubungan dengan peningkatan kadar HbA1c pada anggota Klub Prolanis Diabetes Melitus tipe 2 di Kota Padang.

\section{Metode}

Penelitian ini menggunakan desain cross sectional. Populasi penelitian adalah 
seluruh anggota Klub Prolanis di dua Puskesmas yang ada di Kota Padang, yaitu Puskesmas Lubuk Buaya dan Puskesmas Ambacang yang berjumlah 92 orang. Penentuan lokasi didasarkan bahwa kedua Puskesmas tersebut melaksanakan kegiatan Prolanis secara rutin. Sampel penelitian merupakan bagian dari populasi yang dihitung dengan menggunakan rumus Slovin dan didapatkan sampel sejumlah 83 orang. Sampel diambil secara simple random sampling. Kriteria sampel adalah penderita diabetes mellitus tipe 2, sudah mengikuti pengukuran darah sebanyak 3 kali dan bersedia menjadi sampel dalam penelitian.

Data yang dikumpulkan melalui wawancara dengan menggunakan kuesioner terstruktur meliputi data karakteristik sampel, indeks massa tubuh, asupan makanan dan aktivitas fisik. Data kadar HbAlc merupakan data sekunder dari hasil pemeriksaan darah oleh tenaga kesehatan di Puskesmas yang dikumpulkan datanya 1 minggu sebelum dilakukannya pengumpulan data primer (data variabel independen). Data asupan makanan dikumpulkan dengan menggunakan Semi-Quantitative Food Frequency Questionnaires (SQFFQ). Metode SQ-FFQ dapat digunakan dalam menilai asupan makanan dan didapatkannya informasi besaran porsi ${ }^{11}$ dan memberikan estimasi yang baik seperti recall 24 jam. ${ }^{12}$ Buku foto makanan digunakan untuk membantu daya ingat responden. Data riwayat keluarga diperoleh melalui Form Genogram. Data aktivitas fisik responden dikumpulkan melalui kuesioner Baecke Physical Activity Scale yang memuat pertanyaan tentang kegiatan sehari-hari termasuk saat bekerja, berolahraga dan aktivitas pada waktu luang. Kemudian aktivitas fisik dikelompokkan menjadi 3 kategori berdasarkan jumlah skor jawaban dari responden, yaitu (1) Aktivitas fisik ringan apabila jumlah skor $<5,6$, (2) Aktifitas fisik sedang, apabila jumlah skor 5,6-7,9, (3) Aktivitas fisik berat apabila jumlah skor $>7,9 .^{13,14}$ Pengelompokkan kadar HbAlc adalah menurut American
Diabetes Association (ADA) yang merekomendasikan cut of point $6,5 \%$ dalam penentuan diagnosa diabetes sebagai alternatif glukosa darah puasa, ${ }^{7}$ begitu juga the International Diabetes Federation (IDF) and the European Association for the Study of Diabetes (EASD). ${ }^{15}$

Data yang telah dikumpulkan berikutnya dianalisis secara univariat, bivariat dan multivariat dengan menggunakan program SPSS. Analisis univariat disajikan berupa nilai rata-rata, standar deviasi, nilai minimum, nilai maksimum, frekuensi dan persentase. Analisis bivariat dilakukan untuk mengetahui hubungan atau perbedaan antara variabel independen dengan variabel dependen. Analisis bivariat yang digunakan pada penelitian ini adalah uji chi-square, apabila kedua variabel (dependen dan independen) berupa data kategorik. Nilai Odds Ratio (OR) yang diperoleh dari uji chi-square juga ditampilkan pada hasil untuk mengetahui besaran risiko dari variabel yang diuji dengan tingkat kepercayaan $\quad 95 \% \quad(95 \% \quad$ Confident Interval). Selain itu, uji T-independent digunakan apabila salah satu varibel yang diteliti berupa data numerik. Uji T-independent digunakan untuk mengetahui perbedaan asupan makanan berdasarkan kategori kadar HbA1c berisiko tinggi dan rendah. Adanya perbedaan signifikan nilai mean dari asupan makanan terhadap kategori kadar $\mathrm{HbAlc}$ diketahui dari nilai Pvalue $<0,05$.

Tahapan terakhir dari analisis data penelitian ini adalah dilakukannya analisis mulivariat dengan uji regresi linear berganda. Uji ini digunakan untuk mengetahui faktor yang dapat memprediksi perubahan kadar $\mathrm{HbA1c}$ atau faktor yang berhubungan dengan kadar HbAlc. Sebelum masuk kedalam model atau seleksi variabel independen masuk model, terlebih dahulu dilakukan uji chi-square bagi variabel dengan bentuk data kategorik untuk diketahuinya nilai signifikan variabel independen terhadap variabel dependen (nilai Pvalue). Apabila dari hasil uji 
diperoleh nilai Pvalue $<0,25$ maka variabel independen tersebut dapat masuk ke dalam model regresi linear berganda. Selain pertimbangan dari hasil statistik tersebut, variabel independen dimasukkan dalam model juga mempertimbangkan substansi hubungan variabel tersebut atau dengan peningkatan kadar HbAlc (berdasarkan studi literatur). ${ }^{16}$ Faktor-faktor yang dimasukkan dalam model regresi linear adalah yang telah memenuhi eksistensi, linieritas, independensi, homoscedascity dan normalitas. ${ }^{17}$ Penjelasan masing-masing asumsi sebagai berikut; (1) Eksistensi diketahui melalui analisis deskriptif variabel residual dari model, apabila residual menunjukkan adanya mean dan sebaran maka asumsi eksistensi terpenuhi, (2) Linieritas diketahui dari uji Anova (overall $F$ test) bila hasilnya signifilan (Pvalue $<\alpha$ ) maka model berbentuk linier, (3) Independensi, dilakukan dengan cara mengeluarkan uji Durbin Watson, bila nilai Durbin -2 s.d +2 berarti asumsi independensi terpenuhi, (4) Homoscedascity, diketahui dengan melakukan pembuatan plot residual. Apabila data menyebar di sekitar garis diagonal dan mengikuti arah garis diagonal maka asumsi terpenuhi, dan (5) Normalitas, dapat dilihat dari gambar Normal P-P Plot. Kriteria sebuah (data) residual terdistribusi normal atau tidak dengan pendekatan Normal P-P Plot dapat dilakukan dengan melihat sebaran titik-titik yang ada pada gambar. Apabila sebaran titik-titik tersebut mendekati atau rapat pada garis lurus (diagonal) maka dikatakan bahwa (data) residual terdistribusi normal, namun apabila sebaran titik-titik tersebut menjauhi garis maka tidak terdistribusi normal. ${ }^{18}$

Penelitian dilaksanakan berdasarkan persetujuan dari Program Studi Ilmu Gizi Fakultas Kesehatan Masyarakat Universitas Andalas, Padang (Pengurusan izin penelitian Nomor Surat: 3826/UN16.12/WD1/KM 2017).

Kemudian data responden dikumpulkan setelah responden mengisi dan menyetujui lembaran inform consent sebagai bukti kesediaan sebagai responden dalam penelitian ini.

\section{Hasil}

Hasil penelitian mendapatkan rata-rata kadar $\mathrm{HbAlc}$ responden adalah $7,9 \%( \pm 2,4 \%)$. Hasil tersebut menunjukkan rata-rata kadar $\mathrm{HbAlc}$ pada responden lebih besar dari angka cut of point kadar $\mathrm{HbAlc}$ sehingga responden berisiko tinggi untuk mengalami komplikasi penyakit. Variabel kadar HbAlc dikelompokkan menjadi 2 (dua) kategori yaitu kategori HbAlc yang berisiko tinggi komplikasi ( $\geq$ $6,5 \%$ ) dan risiko rendah komplikasi (< $6,5 \%)$. Hasil analisis didapatkan persentase anggota Klub Prolanis dengan kadar $\mathrm{HbA} 1 \mathrm{c}$ risiko tinggi komplikasi lebih besar, yaitu $65,1 \%$ dan persentase anggota Klub Prolanis dengan kadar $\mathrm{HbA1C}$ risiko rendah komplikasi, yaitu 34,9\%.

Pada tabel 1 dapat dilihat kategori kadar $\mathrm{HbA1c}$ menurut umur, jenis kelamin, riwayat keluarga, status gizi dan aktifitas fisik dengan menggunakan Uji Chi-Square. Hasil analisis pada tabel 1 menunjukkan bahwa kadar HbA1c dengan kategori risiko tinggi lebih banyak terdapat pada responden dengan umur $<60$ tahun (71,4\%) dibandingkan responden dengan umur $\geq 60$ tahun (58,5\%). Responden perempuan memiliki persentase lebih besar memiliki kadar HbAlc dengan kategori risiko tinggi $(66,7 \%)$ dibandingkan responden laki-laki (61,5\%). Responden yang memiliki riwayat keluarga DM $(85,5 \%)$ memiliki persentase lebih besar dengan kadar HbA1c kategori risiko tinggi dibandingkan dengan responden tidak memiliki riwayat DM $(4,8 \%)$. Kemudian hasil analisis diketahui responden dengan status gizi kurang $(100 \%)$ dan status gizi lebih $(94,0 \%)$ lebih banyak memiliki kadar HbA1c dengan kategori risiko tinggi dibandingkan dengan responden dengan status gizi normal (16,1\%). Selanjutnya kadar HbA1c dengan kategori risiko tinggi lebih banyak terdapat pada responden dengan aktifitas fisik ringan (100,0\%) dibandingkan responden dengan aktifitas 
Tabel 1. Distribusi Kadar HbA1c berdasarkan Karakteristik Responden

\begin{tabular}{|c|c|c|c|c|c|c|c|}
\hline \multirow{3}{*}{ Variabel } & \multirow{3}{*}{ Kategori } & \multicolumn{4}{|c|}{ Kadar HbA1c } & \multirow{3}{*}{ Pvalue } & \multirow{3}{*}{$\begin{array}{c}\text { OR } \\
(95 \% \mathrm{CI})\end{array}$} \\
\hline & & \multicolumn{2}{|c|}{$\begin{array}{l}\text { Risiko } \\
\text { Tinggi }\end{array}$} & \multicolumn{2}{|c|}{$\begin{array}{c}\text { Risiko } \\
\text { Rendah } \\
\end{array}$} & & \\
\hline & & $\mathbf{n}$ & $\%$ & $\mathbf{n}$ & $\%$ & & \\
\hline \multirow[t]{2}{*}{ Umur } & Berisiko tinggi ( $\geq 60$ tahun) & 24 & 58,5 & 17 & 41,5 & 0,255 & - \\
\hline & Berisiko rendah $(<60$ tahun $)$ & 30 & 71,4 & 12 & 28,6 & & \\
\hline \multirow[t]{2}{*}{ Jenis kelamin } & Perempuan & 38 & 66,7 & 19 & 33,3 & 0,804 & - \\
\hline & Laki-laki & 16 & 61,5 & 10 & 38,5 & & \\
\hline \multirow[t]{2}{*}{ Riwayat keluarga } & Ada & 53 & 85,5 & 9 & 14,5 & 0,001 & 117,78 \\
\hline & Tidak ada & 1 & 4,8 & 20 & 85,2 & & $(14,010-990,140)$ \\
\hline \multirow[t]{3}{*}{ Status gizi } & Lebih & 47 & 94 & 3 & 6 & 0,001 & - \\
\hline & Normal & 5 & 16,1 & 26 & 83,9 & & \\
\hline & Kurang & 2 & 100 & 0 & 0 & & \\
\hline \multirow[t]{3}{*}{ Aktifitas fisik } & Ringan & 12 & 100 & 0 & 0 & 0,001 & - \\
\hline & Sedang & 40 & 71,4 & 16 & 28,6 & & \\
\hline & Berat & 2 & 13,3 & 13 & 86,7 & & \\
\hline
\end{tabular}

Tabel 2. Perbedaan Rata-rata Asupan Makanan Berdasarkan Kadar HbAlc

\begin{tabular}{llcc}
\hline \multicolumn{1}{c}{ Variabel } & \multicolumn{1}{c}{ Kadar HbA1c } & Mean $( \pm$ SD) & Pvalue \\
\hline Asupan energi (kalori) & Risiko tinggi DM & $2005,81( \pm 308,64)$ & \multirow{2}{*}{0,035} \\
& Risiko rendah DM & $1855,40( \pm 296,84)$ & \\
Asupan karbohidrat (gram) & Risiko tinggi DM & $287,79( \pm 59,40)$ & 0,120 \\
& Risiko rendah DM & $310,47( \pm 68,67)$ & \\
Asupan lemak (gram) & Risiko tinggi DM & $54,26( \pm 10,66)$ & 0,001 \\
& Risiko rendah DM & $36,93( \pm 8,02)$ & \\
Asupan protein (gram) & Risiko tinggi DM & $68,28( \pm 15,87)$ & 0,320 \\
& Risiko rendah DM & $71,62( \pm 11,50)$ & \\
Asupan kolesterol (gram) & Risiko tinggi DM & $234,69( \pm 93,67)$ & 0,001 \\
& Risiko rendah DM & $181,00( \pm 51,04)$ & \\
Asupan serat (gram) & Risiko tinggi DM & $9,56( \pm 2,59)$ & \multirow{2}{*}{0,001} \\
& Risiko rendah DM & $22,38( \pm 95,10)$ & \\
\hline
\end{tabular}

fisik sedang $(71,4 \%)$ dan berat $(13,3 \%)$. Hasil analisis uji chi-square diperoleh riwayat keluarga, status gizi dan aktifitas fisik berhubungan dengan kadar $\mathrm{HbA} 1 \mathrm{c}$ responden (nilai $\mathrm{p}<0,05$ ).

Analisis bivariat dengan menggunakan uji t-independen dilakukan untuk mengetahui perbedaan asupan makanan meliputi asupan energi, karbohidrat, protein, lemak, kolesterol dan serat berdasarkan kadar HbA1c. Hasil analisis dapat dilihat pada tabel 2.

Hasil Uji t-independen diperoleh informasi nilai rata-rata asupan energi terbukti signifikan lebih tinggi pada responden dengan kadar $\mathrm{HbAlc}$ kategori risiko tinggi komplikasi $(2005,81$ kalori \pm $308,64)$ dibandingkan responden dengan kadar HbA1c kategori risiko rendah $(1855,40$ kalori $\pm 296,84)$. Kemudian juga didapatkan rata-rata asupan lemak, asupan kolesterol dan asupan serat responden terbukti signifikan lebih tinggi pada kelompok kadar $\mathrm{HbAlc}$ risiko tinggi dibandingkan responden dengan kadar HbAlc kategori risiko rendah, berturut turut angkanya 54,26 gram $\pm 10,66,234,69$ gram \pm 93,67 dan 9,56 gram $\pm 2,59$ versus berturut-turut 36,93 gram $\pm 8,02,181,00$ gram $\pm 51,04$ dan 22,38 gram $\pm 95,10$ (nilai $\mathrm{p}<0,05)$.

Analisis lebih lanjut melalui analisis multivariat dengan uji regresi linier ganda dilakukan untuk mengetahui faktor yang paling berhubungan dengan peningkatan kadar $\mathrm{HbAlc}$ pada responden. Pada analisis 
ini jenis data kadar HbAlc sebagai variabel dependen berupa data kontinu, begitu juga variabel independen berupa data kontinu kecuali variabel riwayat keluarga, status gizi dan aktifitas fisik berupa data kategori. Faktor-faktor yang dihubungkan dengan peningkatan kadar $\mathrm{HbAlc}$ adalah faktor yang memenuhi syarat masuk model dalam uji regresi linier ganda (nilai Pvalue $<0,25$ ) dan secara substansi dari hasil penelitian terdahulu (studi literatur) berhubungan dengan kadar HbA1c yaitu faktor umur, status gizi, aktifitas fisik, riwayat keluarga, asupan energi, asupan karbohidrat, asupan serat, asupan lemak dan asupan kolesterol (Tabel 3).

Tabel 3. Analisis Multivariat Faktor yang Berhubungan dengan Kadar HbAlc

\begin{tabular}{lccc}
\hline \multicolumn{1}{c}{ Variabel } & $\boldsymbol{\beta}^{*}$ & $\mathbf{9 5 \%} \mathbf{C I}$ & Pvalue \\
\hline Model awal & & & \\
Umur responden & $-0,023$ & $-0,053-0,039$ & 0,759 \\
Status gizi & 0,654 & $-0,124-0,196$ & 0,654 \\
Aktifitas fisik & $-0,131$ & $-3,520--0,714$ & 0,004 \\
Riwayat keluarga & 0,003 & $-1,102-1,135$ & 0,977 \\
Asupan energi & 0,428 & $0,001-0,006$ & 0,012 \\
Asupan karbohidrat & $-0,299$ & $-0,024-0,001$ & 0,066 \\
Asupan serat & $-0,264$ & $-0,200-0,018$ & 0,101 \\
Asupan lemak & $-0,139$ & $-0,078-0,024$ & 0,302 \\
Asupan kolesterol & 0,148 & $0,000-0,009$ & 0,065 \\
Model akhir & & & \\
Aktifitas fisik & $-0,425$ & $-3,400--0,915$ & 0,001 \\
Asupan energi & 0,164 & $0,000-0,002$ & 0,021 \\
Asupan serat & $-0,357$ & $-0,207--0,039$ & 0,005 \\
\hline \multicolumn{3}{c}{$\boldsymbol{\beta}=$ Beta coefficient } &
\end{tabular}

Hasil analisis multivariat pada model akhir menunjukkan bahwa aktifitas fisik (Pvalue $=0,001 ; \beta=-0,425 ; 95 \% \mathrm{CI}=-3,400$ $-0,915$ ), asupan energi (Pvalue $=0,021$; $\beta=0,164 ; 95 \% \mathrm{CI}-0,000 ; 0,002)$ dan asupan serat (Pvalue $=0,005 ; \quad \beta=-0,357$; $95 \% \mathrm{CI}=-0,207--0,039)$ merupakan faktor yang signifikan dapat menjelaskan atau memprediksi peningkatan kadar HbAlc pada responden. Penelitian ini menunjukkan bahwa peningkatan kadar HbAlc responden dalam penelitian ini dihubungkan dengan peningkatan asupan energi, aktifitas fisik rendah dan penurunan asupan serat pada anggota Klub Prolanis. Berdasarkan nilai Beta coefficient, diketahui bahwa faktor aktifitas fisik merupakan faktor yang paling berhubungan dalam mengontrol kadar $\mathrm{HbA} 1 \mathrm{c}$ responden pada penelitian ini.

\section{Pembahasan}

Secara umum hasil penelitian ini sejalan dengan temuan Utomo, dkk di Puskesmas Bahu Kecamatan Malalayang
Kota Manado. ${ }^{18}$ Pada penelitian ini, responden yang menderita DM lebih banyak memiliki status gizi lebih dibandingkan dengan status gizi tidak lebih (normal). Risiko lebih besar dialami oleh individu dengan status gizi lebih untuk mengalami DM dibandingkan status gizi normal. Hal ini dihubungkan dengan kondisi tidak normal dari komponen sindrom metabolik (salah satunya adalah dari kadar glukosa darah) pada individu dengan status gizi lebih atau obesitas dibandingkan dengan status gizi normal. Kondisi obesitas juga dihubungkan dengan peningkatan jaringan adiposa atau distribusi jaringan adiposa yang tidak proporsional pada bagian sentral dan peripheral tubuh yang dikaitkan juga dengan berkembangnya resistensi insulin, intoleransi glukosa, dislipidemia dan penyakit jantung koroner sehingga rentan terhadap perkembangan DM tipe $2 .{ }^{19}$ Studi Yoosuk Jekal, dkk menunjukkan individu dengan status gizi lebih memiliki risiko 3,02 kali dengan kadar glukosa darah puasa 
tidak normal dibandingkan dengan individu yang sehat. Begitu juga temuan Katzmarzyk yang menyebutkan individu dengan status gizi lebih dan obesitas memiliki risiko masing-masing 4,7 kali dan 30,6 kali di diagnosa mengalami sindrom metabolik dibandingkan individu dengan status gizi normal. ${ }^{20}$

Pada penelitian ini diperoleh informasi persentase kadar HbA1c dengan kategori berisiko tinggi hampir sebahagian besar terdapat pada responden yang memiliki riwayat keluarga DM. Hasil yang sama didapatkan oleh Utomo bahwa penderita DM lebih besar persentasenya pada responden yang memiliki riwayat keluarga DM dibandingkan tidak memiliki riwayat $\mathrm{DM}^{18}$. Temuan ini sejalan dengan penelitian Young-Hoon Lee, dkk yang menemukan risiko lebih besar untuk meningkatnya kadar HbA1c pada kelompok yang memiliki riwayat keluarga DM dibandingkan tidak memiliki riwayat DM. Kemungkinan risiko DM diturunkan ibu melalui kehamilan walaupun mekanismenya perlu penelitian lebih lanjut. Namun dari beberapa studi menunjukkan risiko lebih besar diturunkan dari ibu kepada anaknya dibandingkan dari ayah kepada anaknya. ${ }^{21,22}$ Adanya paparan janin terhadap hiperglikemia ibu selama kehamilan kemungkinan dapat menjelaskan terjadinya DM setelah bayi dilahirkan. Selain itu berkembangnya DM pada anak dapat terjadi melalui mutasi yang diturunkan ibu dari DNA mitokondria. Penjelasan lainnya adalah ibu lebih banyak menghabiskan waktunya dalam mengasuh anak dibandingkan ayah sehingga kebiasaan makan termasuk makanan yang disukai dan tidak disukai serta perilaku terkait gaya hidup secara kuat dipengaruhi dari kebiasaan makan atau gaya hidup ibu. ${ }^{21}$

Kombinasi asupan makanan dan aktifitas fisik dibutuhkan dalam pengendalian kadar gula darah bagi penderita Diabetes Melitus, terutama Diabetes Melitus tipe 2. Asupan makanan sumber energi tinggi, asupan serat dan aktifitas fisik yang rendah akan meningkatkan resistensi insulin meskipun belum terjadi peningkatan berat badan yang signifikan. Dari penelitian ini secara signifikan membuktikan bahwa asupan energi, asupan serat dan aktifitas fisik merupakan faktor-faktor yang berkontribusi terhadap peningkatan kadar HbA1c pada penderita DM tipe anggota Klub Prolanis selain asupan serat responden.

Konsumsi serat sangat besar sekali perannya dalam mengurangi risiko penyakit degeneratif termasuk Diabetes Melitus tipe 2. ${ }^{2,24}$ Secara spesifik, hasil studi meta analisis menunjukkan konsumsi serat dalam jumlah banyak terutama serat sereal memberikan manfaat dalam penurunan insiden berkembangnya DM tipe 2. Selain itu didapatkan informasi adanya sedikit penurunan konsentrasi glukosa darah puasa begitu juga penurunan persentase hemoglobin terglikosilasi (HbAlc) pada individu dengan DM tipe 2 yang menambahkan $\beta$-glukan atau psyllium dalam asupan makanan setiap harinya. ${ }^{25}$

Penelitian ini menemukan bahwa responden dengan asupan serat rata-rata sekitar 20 gram per hari memiliki kadar HbA1c yang terkontrol (tabel 2). Penderita DM dianjurkan mengkonsumsi serat sekitar 20 gram $/ 1000 \mathrm{kkal}$ per harinya terutama serat larut. Dengan mengkonsumsi serat dalam jumlah cukup dapat memberikan manfaat metabolik diantaranya pengendalian terhadap kadar gula darah, hiperinsulinemia dan kadar lipid plasma atau faktor risiko kardiovaskuler. ${ }^{26}$ Penerapan pola makan yang baik terutama asupan serat yang cukup sesuai kebutuhan dan disertai dengan pola aktifitas fisik yang teratur dapat mengontrol kadar $\mathrm{HbAlc}$. Hasil penelitian menunjukkan aktifitas fisik merupakan faktor yang paling berperan terhadap pengendalian kadar HbAlc. Penelitian ini membuktikan persentase paling besar risiko untuk meningkatnya kadar HbAlc adalah pada responden dengan aktifitas fisik ringan dibandingan aktifitas fisik sedang dan berat. Temuan ini sejalan dengan hasil penelitian Najafipour 
dan Beraki bahwa aktifitas fisik yang dilakukan secara rutin dan jangka waktu yang lama akan memberikan efek yang signifikan terhadap kadar $\mathrm{HbAlc}$ pada kelompok eksperimen. ${ }^{27,28}$ Oleh karena itu, perlu dimonitor kegiatan dari anggota klub Prolanis agar kegiatan dapat diikuti secara rutin, termasuk kegiatan senam atau olah raga dan kegiatan edukasi.

\section{Kesimpulan}

Asupan energi, asupan serat dan aktifitas fisik merupakan faktor-faktor yang berhubungan dengan peningkatan kadar HbAlc anggota Klub Prolanis di Puskesmas Lubuk Buaya dan Puskesmas Ambacang. Faktor yang paling berperan terhadap kadar HbAlc adalah Aktifitas Fisik. Dengan demikian diharapkan anggota Klub Prolanis Diabetes Melitus tipe 2 menerapkan aktifitas fisik yang aktif sesuai dengan kondisi fisik dan mengkonsumsi serat yang cukup, disamping menurunkan konsumsi makanan sumber energi tinggi sehingga kadar glukosa terkontrol atau kadar HbAlc menurun dan risiko untuk mengalami komplikasi menjadi rendah. Peneliti selanjutnya disarankan untuk melakukan studi kualitatif mengenai evaluasi kegiatan Prolanis di Puskesmas sehingga didapatkan informasi lebih mendalam pelaksanaan kegiatan Prolanis, pemahaman dan penerapan pola hidup sehat termasuk pola makan dan aktifitas fisik anggota klub Prolanis.

\section{Ucapan Terima Kasih}

Penulis berterima kasih kepada seluruh responden penelitian yang sudah meluangkan waktunya untuk diwawancarai. Kepada Dinas Kesehatan Kota Padang, Puskesmas Lubuk Buaya dan Puskesmas Ambacang yang telah memberikan ijin dan membantu tim peneliti untuk dapat melakukan penelitian ini sehingga berjalan dengan lancar. Ucapan terima kasih juga disampaikan kepada Dekan Fakultas Kesehatan Masyarakat Universitas Andalas (FKM Unand) beserta pimpinan lainnya yang telah mendukung dan memberikan izin serta staf FKM Unand yang telah membantu segala hal terkait administrasi untuk kelancaran proses penelitian ini.

\section{Daftar Pustaka}

1. World Health Organization (WHO). Global health risks: mortality and burnen of disease attributable to selected major risks Geneva. WHO Press. 2017.

2. Kramer CK, et al. Risk factors for micro and macrovascular disease in black and white patients with type 2 Diabetes Melitus. Rev Assoc Med Bras. 2009;55:308-314.

3. IDF, editor. International Diabetes Federation. 2015.

4. Badan Penelitian dan Pengembangan Kesehatan Kementrian Kesehatan RI. Hasil Riskesdas Tahun 2018: Kementrian Kesehatan RI; 2018.

5. Badan Penelitian dan Pengembangan Kesehatan Kementrian Kesehatan RI. Hasil Riskesdas Tahun 2013: Kementrian Kesehatan RI; 2013.

6. World Health Organization (WHO). Use of Glycated Haemoglobin (HbA1c) in the Diagnosis of Diabetes Melitus Abbreviated Report of a WHO Consultation. Geneva: WHO; 2011.

7. Shariq I. Sherwani, et al. Significance of HbA1c Test in Diagnosis and Prognosis of Diabetic Patients. Biomark Insights. 2016;11:95-104.

8. Anani S, A U, P G. Hubungan Antara Perilaku Pengendalian Diabetes dan Kadar Glukosa Darah Pasien Rawat Jalan Diabetes Melitus (Studi Kasus di RSUD Arjawinangun Kabupaten Cirebon). Jurnal Kesehatan Masyarakat. 2012:1,466-478.

9. Harum A., TA L, R. Z. Hubungan Diet Serat Tinggi Dengan Kadar HbA1c Pasien Diabetes Melitus Tipe 2 Di RSUD DR.H. Abdul Moeloek Provinsi Lampung. Jurnal Major,. 2013;2(4).

10. Betteng R. Analisis Faktor Resiko Penyebab Terjadinya Diabetes Melitus Tipe 2 Pada Wanita Usia Produktif Dipuskesmas Wawonasa. Jurnal E-Biomedik. 2014;2(2):404-412.

11. Ivonne Ramírez-Silv, et al. Methodology for estimating dietary data from the semi-quantitative food frequency questionnaires of the Mexican National Health and Nutrition Survey 2012. Salud pública de méxico. 2016;5.

12. Shahril Mohd Razif, et al. Semi-Quantitative Food Frequency Questionnaire for Assessment of Energy, Total Fat, Fatty Acids, and Vitamin A, C and E Intake among Malaysian Women: Comparison with Three Days 24-Hour Diet Recalls. 2008. https://www.researchgate.net/publication/23227 1907_Semi-Quantitative_Food_Frequency_Que stionnaire_for_Assessment_of_Energy_Total_F at_Fatty_Acids_and_Vitamin_A_C_and_E_Inta 
ke_among_Malaysian_Women_Comparison_wi th_Three_Days_24-Hour_Diet_Recalls.

13. Baecke J, J B, J. F. A Short Questionnaire for the Measurement of Habitual Physical Activity in Epidemiological Studies. J Clin Nutr. 1982:3642.

14. Mahshid Dehghan, et al. Validation of a Semi-Quantitative Food Frequency Questionnaire for Argentinean Adults. 2012.

15. Raul A Martin, et al. Glycated hemoglobin and associated risk factors in older adults. ardiovascular Diabetology. 2012;11(13).

16. Wakkee M, et al. Multivariable Analysis. Journal of Investigative Dermatology. 2014;134(20).

17. Anonim. 16-18.

18. Utomo, et al. Kadar HbA1c pada Pasien Diabetes Melitus Tipe 2 Di Puskesmas Bahu Kecamatan Malalayang Kota Manado. Jurnal e-Biomedik (eBm). 2015;3(1).

19. Jayesh Sheth, et al. The association of dyslipidemia and obesity with glycated hemoglobin. Clin Diabetes endrocinol. 2015;1(6).

20. Yoonsuk Jekal, et al. Association between Obesity and Physical Fitness, and Hemoglobin A1c level and Metabolic Syndrome in Korean Adults. Korean Diabetes J. 2010;34(3):182-190.

21. Young-Hoon Lee, et al. Effect of Family History of Diabetes on Hemoglobin A1c levels among individuals with and without Diabetes : The Dong-gu Study. Yonsei Medical Journal. 2018;59(1):92-100.
22. Ming Wu. Familial History of Diabetes is Associated with Poor Glycaemic Control in Type 2 Diabetics: A Cross-sectional Study. Sci Rep. 2017;7.

23. Robert E Post. Dietary Fiber for the Treatment of Type 2 Diabetes Melitus: A Meta-Analysis. The Journal of the American Board of Family Medicine. 2012;25(1):16-23.

24. Hiroki Fujii, et al. Impact of dietary fiber intake on glycemic control, cardiovascular risk factors and chronic kidney disease in Japanese patients with type 2 Diabetes Melitus: the Fukuoka Diabetes Registry. Nutrition Journal. 2013;12(159).

25. Marc P. McRae. Dietary Fiber Intake and Type 2 Diabetes Melitus: An Umbrella Review of Meta-analyses. J Chiropr Med. 2018;17(1):4453.

26. Azrimaidaliza. Asupan Zat Gizi dan Penyakit Diabetes Melitus. Jurnal Kesehatan Masyarakat Andalas. 2011;6(1).

27. Najafipour F, et al. Effect of regular exercise training on changes in HbAlc, BMI and VO2max among patients with type 2 diabetes mellitus: an 8-year trial. BMJ Open Diabetes Res Care. 2017;5(1).

28. Beraki A, et al. Increase in physical activity is associated with lower HbA1c levels in children and adolescents with type 1 diabetes: Results from a cross-sectional study based on the Swedish pediatric diabetes quality registry (SWEDIABKIDS). Diabetes Research and Clinical Practice. 2014;105(1). 